\title{
CONCEPT OF «INDEPENDENT WORK» IN PROFESSIONAL TRAINING OF FUTURE SERVICE SPECIALISTS
}

\section{КОНЦЕПТ «САМОСТІЙНА РОБОТА» В ПРОФЕСІЙНІЙ ПІДГОТОВЦІ МАЙБУТНІХ ФАХІВЦІВ СФЕРИ ОБСЛУГОВУВАННЯ}

\author{
Olha SOZONIUK, \\ Postgraduate student \\ Ольга СОзОНюК, \\ аспірантка \\ olhahrushnik@gmail.com \\ https://orcid.org/0000-0002-8482-5071 \\ Larysa SAVCHENKO, \\ Doctor of pedagogical sciences, \\ professor \\ yniverola2017@gmail.com \\ ЛарИса САВЧЕНКО, \\ доктор педагогічних наук, \\ профресор \\ https://orcid.org/0000-0002-4246-3228 \\ Kryvyi Rih State Pedagogical \\ University \\ 26, Haharyna avenue, Kryvyi \\ Rih, Dnipropetrovsk region, 50027 \\ Original manuscript received: October 07, 2021 \\ Revised manuscript accepted: December 15, 2021
}

\begin{abstract}
At the present stage of all industry spheres development, the service sector is a leader, because it trains specialists who are directly involved in the development of Ukraine's economy. The efficiency of the enterprise operation and the level of customer service depend on their competence, competitiveness, independence, speed of decision-making. The main task of high school is to teach applicants to work independently, look forward self-improvement, think creatively, be ready for innovation. That is why there is a need to strengthen the role of independent work of students, which is a key in the process of training future professionals capable of performing complex production tasks at a high professional level.

The purpose of the article is to analyze the essence of the concepts «independent», «individual», "extracurricular» work, "self-education» and «independence»; characterize common and distinctive features; isolate our own vision of understanding the essence of the studied phenomena. We should note that the terms «independent work», «individual work», "extracurricular work», "self-education» and «independence» researchers have different meanings, because today there are many approaches to defining the essence of these concepts, and as a consequence - many interpretations, but there are not enough researches, which systematically presents the generalized scientific achievements on the essence of the studied concepts, their common and distinctive features. To understand the relationship between independent, individual work and self-education of students, it is necessary to consider the basic approaches to the definition of basic concepts in pedagogical science.

The results of the analysis of the essence of independent, individual, extracurricular work, independence and self-education of the individual show that these are
\end{abstract}


complex activities that can be interconnected, coincide at different stages of development or in general. Despite the different approaches to determining the essence of the studied phenomena, their structure contains the same components: subject, object, purpose, content, means, result. The paper presents an analysis of the psychological and pedagogical literature on the interpretation of the concepts being studied; common and distinctive features are singled out; substantiated own vision of the studied phenomena.

Key words: independent work, individual work, extracurricular work, selfeducation, independence.

Вступ. Стрімке зростання новітніх комп'ютерних та інформаційних технологій, соціально-економічні реалії сьогодення, входження України в Європейське співтовариство, зокрема в Болонський процес, зумовлюють підвищення вимог, які висуваються до професійних якостей людини. Сучасні тенденції розвитку економіки, де основним, ефективним та працездатним ресурсом стає мобільний і висококваліфікований «людський капітал», потребують нової якості вищої освіти. Тому цілком доречно, що шляхи, методи та прийоми реформування вищої освіти вимагають переосмислення та перегляду підходів до її організації, результатом якої має стати розвиток таких професійних та особистісних компетентностей, як внутрішня готовність до саморозвитку та самоосвіти, самостійність та відповідальність, ініціативність і творча активність.

Саме тому в сучасному освітньому просторі постало суттєве і водночас складне питання - організація самостійної роботи майбутніх фахівців загалом і сфери обслуговування зокрема. Важливість цієї проблеми зумовлена новою роллю самостійної роботи, якої вона набуває у зв'язку з переходом на діяльнісну парадигму освіти. Самостійна робота стає провідною фрормою організації освітнього процесу в умовах економічного розвитку та пандемії. У цьому процесі слід виокремити, проаналізувати та порівняти основні поняття - самостійна, індивідуальна і позааудиторна роботи, самоосвіта й самостійність: чи слід ототожнювати ці явища, які відмінності існують, яке співвідношення між ними.

Проблема самостійної роботи не нова в науковій царині. П̈ї започаткували педагоги-класики й суспільні діячі минулого А. Дістервег, Д. Дьюї, Й. Песталоцці, Ж.-Ж. Руссо, О. Остроградський, М. Пирогов, К. Ушинський, К. Яновський та ін. Сутність та зміст поняття, а також підходи й засоби організації самостійної роботи охарактеризували В. Буряк, М.Гарунов, В.Граф, Н. Дайрі, В. Євдокимов, І. Ільясов, В. Козаков, О. Малихін, Н. Половнікова, О. Савченко та ін.

Питання індивідуальної роботи в професійній підготовці фахівців розкриваються в працях А. Гуревича, Ю. Кулюткіна, Г. Сухобської, А. Кірсанова, Є. Рабунського тощо. У працях М. Гарунова, О. Євдокимова, І. Шайдура, К. Бабенко, О. Мороза, В. Тесленка відображені особливості позааудиторної роботи студентів та її організації. Вивченню явища «самостійності» присвячені наукові дослідження Б. Єсипова, П. Підкасистого, . Недбаєвої, В. Спіріна, 
А. Усової та ін. Значущість поняття «самоосвіти» знайшла своє відображення як у педагогів-класиків (Ф. Дістервег, Я. Каменський, Й. Песталоцці, В. Сухомлинський, К. Ушинський), зарубіжних науковців (І. Герде, В. Оконь), так і вітчизняних учених (В. Буряк, В. Козаков та ін.).

Методи та методики дослідження. Основну мету cmammi вбачаємо у висвітленні, узагальненні та систематизації, а також виокремленні власного погляду на розуміння сутності понять «самостійна робота», «індивідуальна робота», «позааудиторна робота», «самоосвіта» та «самостійність». Завдання дослідження:

- проаналізувати досвід попередників щодо тлумачення понять «самостійна робота», «індивідуальна робота», «позааудиторна робота», «самоосвіта» та «самостійність» ;

- розкрити спільні та відмінні риси досліджуваних понять;

- обґрунтувати власне бачення явищ, які вивчаються.

Результати та дискусії. В умовах модернізації вищої освіти відповідно до запитів сучасного суспільства і виробництва (ринку України необхідні спеціалісти, здатні мислити самостійно, творчо; бути активними, впевненими, відповідальними; вміти жити та працювати в нових умовах) важливою проблемою стає зміна змісту професійної освіти, удосконалення освітнього процесу, де поступово збільшується частка самостійної роботи та її важливість.

Для розуміння співвідношення між самостійною, індивідуальною, позааудиторною роботою, самоосвітою і самостійністю необхідно враховувати основні підходи до визначення цих понять у науці. Явище «самостійна робота» досить складне та багатогранне, адже існує багато шляхів його визначення. Проаналізувавши психолого-педагогічну літературу, можемо зробити висновок, що це поняття вивчається 3 точки зору різних аспектів:

1) як діяльність студентів, організована викладачем та спрямована на досягнення дидактичної мети (О. Алексюк. А. Аюрзанайн, П. Підкасистий, В. Козаков, С. Трубачов);

2) як діяльність студентів із засвоєння знань і вмінь без безпосереднього керівництва викладача, хоча й спрямована ним (В. Загвязинський);

3) засіб організації навчального або наукового пізнання студентів (П. Підкасистий, Л. Фрідман, М. Гарунов);

4) фрорма організації навчальної діяльності (Т. Шамова, Закон України «Про вищу освіту»);

5) вид навчальних занять, діяльності учіння, виконання завдань (С. Архангельський, О. Молибог, Р. Низамов);

6) стимуляція активності студентів (пізнавальної, творчої, інтелектуальної, пошукової).

У педагогічному словнику С. Гончаренка самостійну роботу визначають як «різноманітні види індивідуальної і колективної навчальної діяльності школярів, яка здійснюється ними на навчальних заняттях або дома за завданнями вчителя під його керівництвом, однак без його 
безпосередньої участі» (4). Проте вища школа відрізняється від середньої методикою навчальної роботи та мірою самостійності студентів. Викладач лише виступає модератором. Майбутній фахівець як зріла, майже сфрормована особистість, порівняно зі школярем, виконує пізнавальну діяльність самостійно, що забезпечує розвиток його самостійності як сукупності умінь і навичок, а також рису успішності спеціаліста будь-якої сфери діяльності.

Виходячи з цього, ототожнювати поняття «самостійна робота» та «самостійність» не $є$ коректним, адже самостійність - це властивість або риса особистості, яка характеризується двома фракторами: поперше, сукупність засобів - знань, умінь та навичок, якими володіє особистість; по-друге, ставленням особистості до процесу діяльності, її результатів та умов здійснення, а також зв'язками з іншими людьми, які складаються в процесі діяльності (4). Самостійність - це вміння діяти без сторонньої допомоги або керівництва. А. Брушлинський, О. Матюшкін подають це явище як необхідну умову продуктивних розумових процесів, пов'язаних з постановкою нових проблем і пошук їх розв'язання (11). І. Лернер, П. Підкасистий тлумачать поняття самостійності як здатність учнів розв'язувати пізнавальні завдання (12). А. Громцева, А. Піменова, Г. Щукіна характеризують цей термін як умову активізації навченої діяльності (2).

Самостійність у навчально-пізнавальній діяльності відіграє значну роль. Вона $\epsilon$ важливою складовою в процесі підготовки висококваліфікованого фрахівця. Завдання закладу вищої освіти полягає в активації пізнавальної самостійності здобувача, що допоможе сформувати активного, відповідального, готового до дій, цілеспрямованого фахівця. Саме самостійна робота формує готовність до самоосвіти, створює підґрунтя для самовдосконалення та можливість підвищувати кваліфікацію.

Самоосвіта - це освіта, яка набувається в процесі самостійної роботи без проходження системного курсу навчання в стаціонарному закладі (4). Ми розуміємо під самоосвітою певний вид діяльності особистості, який здійснюється з точки зору її власних уподобань, мети, пізнавальних чи профресійних потреб. I тут неважливо здійснюється ця діяльність під керівництвом викладача чи без його участі, адже процес самоосвіти може відбуватись поза межами ЗВО за власної ініціативи суб'єкта і лише він сам несе відповідальність за ії результати. У цьому і полягає відмінність між самоосвітою, самостійністю й індивідуальною роботою.

Як зазначено в педагогічному словнику С. Гончаренка, індивідуальна робота - це одна із форм організації навчально-виховного процесу, при якій здійснюється педагогічний вплив учителя на учня, котрий перебуває поза колективом (4). У Положенні про організацію навчального процесу в кредитно-модульній системі підготовки фрахівців індивідуальна робота визначається як форма організації освітнього процесу, яка забезпечує реалізацію творчих можливостей студента через індивідуально спрямований розвиток здібностей, науково-дослідну роботу і творчу 
діяльність (13). Тобто, індивідуальна робота студента є організаційним видом самостійної роботи; це аудиторна робота за індивідуальними завданнями під керівництвом викладача, коли в разі потреби студент може отримати методичну допомогу у вигляді консультацій, які носять індивідуальний характер. Завдання викладача - не тільки оцінити студента, але й скоригувати його в разі помилки, допомогти організувати процес самостійного здобуття знань.

Категоріально самостійна та індивідуальна робота пов'язані між собою, так як вони $є$ частковими формами організації освітнього процесу у вищій школі. Однак зазначимо, що самостійна робота суттєво ширше поняття, оскільки вона може здійснюватись у вигляді індивідуальної роботи, а також в інших формах - наприклад, групова самостійна робота. Приклади індивідуальних завдань та самостійної діяльності представлені в таблиці 1.

Завдання самостійної та індивідуальної робіт

Таблиця 1

\begin{tabular}{|c|c|}
\hline Самостійна робота & Індивідуальна робота \\
\hline підготовка до аудиторних занять; & $\begin{array}{l}\text { 1) конспект } 3 \text { теми за власним або } \\
\text { заданим планом; }\end{array}$ \\
\hline $\begin{array}{l}\text { 2) } \quad \text { виконання завдань із навчальної } \\
\text { дисципліни протягом семестру; }\end{array}$ & 2) рефрерат з теми; \\
\hline $\begin{array}{l}\text { 3) робота над окремими темами } \\
\text { навчальних дисциплін, які винесені на } \\
\text { самостійне опрацювання згідно } 3 \\
\text { робочою програмою; }\end{array}$ & $\begin{array}{l}\text { 3) розробка теоретичних або } \\
\text { прикладних функціональних моделей, } \\
\text { явищ, процесів і таке інше; }\end{array}$ \\
\hline $\begin{array}{l}\text { 4) підготовка до во всіх } \\
\text { контрольних випробувань; }\end{array}$ & $\begin{array}{l}\text { 4) підготовка індивідуального творчого } \\
\text { завдання; }\end{array}$ \\
\hline $\begin{array}{l}\text { 5) } \quad \text { виконання } \\
\text { передбачених програмою практики; }\end{array}$ & $\begin{array}{lccc}5) \quad \text { розробка } & \text { навчальних } & \text { та } \\
\text { діагностичних тестових завдань } & \\
\end{array}$ \\
\hline $\begin{array}{l}\text { 6) участь у науковій i науково- } \\
\text { методичній роботі кафедри }\end{array}$ & \\
\hline
\end{tabular}

Ефективність індивідуальної роботи залежить від готовності та вмотивованості суб'єктів цього процесу, професійної підготовки викладача, технічного забезпечення тощо. Правильно організована індивідуальна діяльність фрормує у майбутніх фрахівців самостійні навчальні та професійні дії, допомагає відчувати себе вільно, обирати зручний темп виконання завдань, розуміючи, що тільки від власних дій залежить результат.

Серед науковців немає єдиної думки щодо визначення сутності понятя «позааудиторна робота». Так, В. Коваль вважає, що позааудиторна робота - це система взаємопов'язаної діяльності суб'єктів освітнього процесу, що є невід'ємним складником професійної підготовки і здійснюється поза розкладом навчальних занять, щоб створити умови для особистісного розвитку студентів і їх самореалізації (7).

Л. Онучак наголошує, що це будь-яка діяльність, яка сприяє навчанню поза межами класу і яка не пов'язана 3 навчальною програмою (10). М. Крюкова пропонує розглядати позааудиторну роботу 
як самостійну, що є лабораторією творчого мислення, де студент може найбільш повно проявити свою самостійність, реалізувати навички, отримані в аудиторії (8). О. Куцевол стверджує, що це особлива цілеспрямована форма організації студентського життя, що здійснюється у вільний від навчання час з метою розширення і поглиблення знань, умінь та навичок, розвитку самостійності, індивідуальних здібностей студентів, а також задоволення їхніх інтересів і забезпечення активного й змістовного відпочинку (9).

Позааудиторна робота $€$ логічним продовженням аудиторних занять. Її завдання полягає в тому, щоб розвивати ініціативу та мотивацію до розумової й фрізичної активності; успішно використовувати теоретичні знання на практиці; сприяє естетичному, культурному і творчому вихованню, а також орієнтується на корисну діяльність. Ми пропонуємо під поняттям позааудиторна робота розуміти вид самостійної діяльності суб'єктів освітнього процесу, яка є невід'ємною частиною підготовки фахівців і спрямована на розвиток професійних якостей особистості та здійснюється поза розкладом навчальних занять.

Результати аналізу сутності понять самоосвіти, самостійності, самостійної, індивідуальної та позааудиторної роботи дають нам змогу зробити такі висновки:

1) самоосвіта - це процес навчання, який здійснюється за власним бажанням окремої людини поза межами навчального курсу за рахунок самостійної роботи;

2) самостійність - це риса особистості, яка виховується в результаті самостійної діяльності;

3) індивідуальна і позааудиторна роботи є видами самостійної роботи, які мають одну мету - виховати та підготувати висококваліфрікованого фрахівця;

4) самостійна робота - це спланована діяльність особистості, яка має чітку структуру, мету, цілі й спрямована на розвиток професійних компетентностей.

Тобто, самостійна робота (а разом з нею індивідуальна і позааудиторна як іiї види) - це засіб виховання самостійності, яка сприяє самоосвіті (рис. 1)

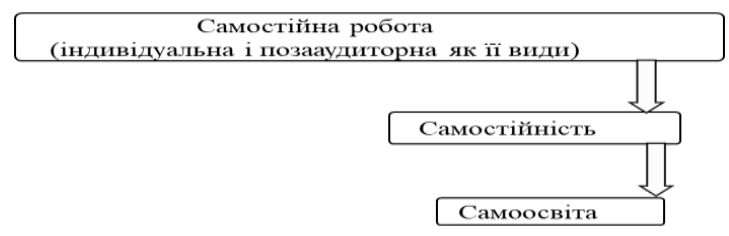

Рис. 1. Співвідношення самостійної, індивідуальної, позааудиторної робіт, самоосвіти та самостійності

Досліджувані поняття $є$ складними видами діяльності, мають багато спільних ознак і за умови ефективної організації та виконання 
сприяють розвитку професійної, всебічно розвиненої, готової до активних дій особистості, яка несе відповідальність за будь-який результат. Якщо студент розуміє позитивний вплив самостійної роботи, її цілі й зацікавлений у досягненні поставленої мети, то в такому випадку самостійна робота може стати його самоосвітньою діяльністю. Як тільки мета перестає бути метою студента, відбувається зворотній шлях від самоосвіти до самостійної роботи. Для того, щоб забезпечити трансформацію самостійної роботи в самоосвіту, необхідно виховати позитивне ставлення до професійно значущих цілей, високий рівень знань, умінь, самостійно працювати 3 інформацією, сформувати організаційно-управлінські компетентності. Незважаючи на широкий спектр підходів до визначення сутності явищ, які аналізуються, їх структура містить однакові компоненти: суб'єкт, об'єкт, мета, зміст, засоби, результат. Тому раціональність самостійної роботи, а разом 3 нею індивідуальної, позааудиторної, самоосвіти і самостійності, залежить від сорормованості її структурних елементів: мотивації (усвідомлення значущості); змістових компонентів на кожному з етапів їх здійснення; методів та прийомів; сорормованості якостей самостійності, самоорганізації, самоконтролю, саморегуляції.

Висновки. Самостійна робота - невід'ємна складова освітнього процесу закладу вищої освіти, що є умовою поглиблення й розширення знань, посилення інтересу до пізнавальної діяльності, фрормування творчої особистості фахівця, здатного до саморозвитку й самореалізації. Самостійна робота набуває нової ролі у зв'язку з переходом на діяльнісну парадигму освіти, вона $є$ провідною формою організації освітнього процесу. У подальшому дослідженні розглянемо поняття «самостійної роботи», тому що воно лежить в основі самоосвіти й ефективної її організації, сприяє розвитку самостійності студента.

\section{Література}

Алексюк А. Н., $\quad$ Аюрзанайн А. А., Пидкасистый П. И., Козаков В. А. Организация работы студентов в условиях интенсификации обучения. Київ : ИСДО, 1993. С. 6-7.

Буряк В. К. Керівництво самостійною роботою учнів у навчальному процесі. Педагогіка вищої та середньої школи. 2001. Вип. 3. С. 135-145.

Гарунов М. Г., Блохин М. А., Лаптева Г. С. Развитие у студентов опыта самостоятельной профессиональной деятельности. Москва : НИИВШ, 1985. 44с.

Гончаренко С. У. Український педагогічний словник. Київ : Либідь, 1997. 376 с.

Дайри Н.Г. О сущности самостоятельной работы. Народное образование. 1963. № 5. С. 29-34.

Загвязинский В. И. Теория обучения. Современная интерпретация : учеб. пособие для студ. высш. учеб. заведений. Москва : Академия, 2007. 192с.

Коваль В. Ю. Система позааудиторної діяльності студентів вищих навчальних закладів. Наукові праці Донецького національного технічного університету. Серія: «Педагогіка, психологія, соціологія». 2009. № 6. С. 19-23.

Крюкова Н.И. Проблема аудиторной и внеаудиторной работы в вузах США : автореф. дис. на соиск. ученой степени канд. пед. наук : 13.00.01. Москва, 1980. 17 c. 
Куцевол О. М. Методика викладання української літератури (креативноінноваційна стратегія) : монографія. Київ : Освіта України, 2011. 464 с.

Онучак Л. В. Педагогічні умови організації самостійної позааудиторної роботи студентів економічних спеціальностей : автореф. дис. на здобуття наук. ступеня канд. пед. наук : 13.00.04. Київ, 2002. 21 с.

Педагогика : [учеб. пособие для студ.] / ред. П. И. Пидкасистого. Москва : Педагогичекое общество Росии, 1998. 640 с.

Пидкасистый П. И. Сущность самостоятельной деятельности студентов и психолого-дидактические основы её классификации. Проблемы активизации самостоятельной работы студентов. Пермь : Изд-во ПТУ, 1979. С. 23-34.

Положення про організацію навчального процесу в кредитно-модульній системі підготовки фахівців. Тернопіль : ТНПУ, 2004. 48 с.

\section{References}

Aleksyuk, A. N., Ayurzanain, A. A., Pidkasistyi, P. I., Kozakov, V. A. (1993). Organizaciya raboty studentov $v$ usloviyakh intensifikacii obucheniya [Organization of students' work in the conditions of intensification of education]. Kiïv : ISDO [in Russian].

Buryak, V.K. (2001). Kerivnycztvo samostiinoyu robotoyu uchniv u navchalnomu procesi [Guide the independent work of students in the learning process]. Pedagogika vyshhoyi ta serednoyi shkoly - Higher and secondary school pedagogy. 2001, 3, P. 135-145 [in Ukrainian].

Garunov, M. G., Blohin, M. A., Lapteva, G. S. (1985). Razvitie u studentov opyta samostoyatelnoi professionalnoi deyatelnosti [Development of students' experience of independent professional activity]. Moskva : NIIVSH [in Russian].

Goncharenko, S. U. (1997). Ukrayinskyi pedagogichnyi slovnyk [Ukrainian pedagogical dictionary]. Kyiv : Lybid [in Ukrainian].

Dayri, N. G. (1963). O suschnosti samostoyatelnoy raboty [About the essence of independent work]. Narodnoe obrazovanie - Public education, 5, 29-34 [in Russian].

Zagvyazinskiy, V.I. (2007). Teoriya obucheniya. Sovremennaya interpretatsiya [Learning theory. Modern interpretation] : ucheb. posobie dlya stud. vyissh. ucheb. zavedeniy. Moskva : Akademiya [in Russian].

Koval, V. Yu. (2009). Systema pozaaudytornoyi diyalnosti studentiv vyshhyx navchalnyx zakladiv [The system of extracurricular activities of students of higher educational institutions]. Naukovi praci Doneczkogo nacionalnogo texnichnogo universytetu. Seriya: «Pedagogika, psyxologiya, sociologiya», 6, 19-23 [in Ukrainian].

Kryukova, N. I. (1980). Problema auditornoi $i$ vneauditornoi rabotyi v vuzah SShA [The problem of classroom and extracurricular work in US universities]. (Thesis abstract). Moskva [in Russian].

Kuczevol, O. M. (2011). Metodyka vykladannya ukrayinskoyi literatury (kreatyvno-innovaciina strategiya) [Methods of teaching Ukrainian literature (creative and innovative strategy)]: monografiya. Kyiv : Osvita Ukrainy [in Ukrainian].

Onuchak, L. V. (2002). Pedagogichni umovy organizacii samostijnoyi pozaaudytornoyi roboty studentiv ekonomichnyx specialnostei [Pedagogical conditions for organizing independent extracurricular work of students of economic specialties]. (Thesis abstract). Kyiv [in Ukrainian].

Pidkasistyi, P. I. (Ed.) (1998). Pedagogika [Pedagogy]. Moscow : Pedagogical community of Russia [in Russian].

Pidkasistyi, P. I. (1979) Suschnost samostoyatelnoy deyatelnosti studentov $i$ psihologo-didakticheskie osnovyi eyo klassifikatsii [The essence of independent activity of students and psychological and didactic bases of its classification]. 
Problemy aktivizatsii samostoyatelnoy rabotyi studentov - Problems of activation of independent work of students. Perm : pub. PTU, 23-24 [in Russian].

Polozhennya pro organizaciyu navchalnogo procesu $v$ kredytno-modulnii systemi pidgotovky faxivciv (2004) [Regulations on the organization of the educational process in the credit-module system of training]. Ternopil : TNPU [in Ukrainian].

\section{АНОТАЦІЯ}

На сучасному етапі розвитку індустрії сфрера обслуговування є лідером, адже готує фрахівців, які беруть безпосередню участь в розвитку економіки України. Від їх компетентності, конкурентоспроможності, самостійності, швидкості прийняття рішення залежить ефективність фрункціонування підприємства і рівень обслуговування клієнтів. Головним завданням вищої школи $\epsilon$ навчити здобувачів самостійно працювати, самовдосконалюватись, творчо мислити, бути готовими до інноваційної діяльності. Саме тому виникає потреба посилення ролі самостійної роботи студентів, яка є ключовим важелем у процесі підготовки майбутнього фрахівия, здатного виконувати складні виробничі завдання на високому професійному рівні. Мета статті полягає в аналізі сутності понять "самостійна», «індивідуальна», «позааудиторна» робота, "самоосвіта» та "самостійність»; характеристиці спільних та відмінних рис; виокремленні власного бачення щодо розуміння сутності досліджуваних явищ. Зазначимо, що в терміни «самостійна робота», «індивідуальна робота», «позааудиторна робота», «самоосвіта» та «самостійність» дослідники вкладають різний зміст, тому що на сьогодні існує багато підходів до визначення сутності цих понять, а, як наслідок, безліч трактувань, але не достатньо досліджень, у яких системно подано узагальнений науковий доробок учених щодо сутності досліджуваних понять, їх спільні та відмінні риси. Для розуміння співвідношення між самостійною, індивідуальною роботою та самоосвітою студентів необхідно враховувати основні підходи до визначення основних понять у педагогічній науці. Результати аналізу сутності самостійної, індивідуальної, позааудиторної роботи, самостійності та самоосвіти особистості свідчать, що це складні види діяльності, які можуть бути пов'язані між собою, збігатися на окремих етапах розвитку або й загалом. Незважаючи на різні підходи до визначення сутності досліджуваних явищ, ї структура містить однакові компоненти: суб'єкт, об'єкт, мета, зміст, засоби, результат. У роботі подано аналіз психолого-педагогічної літератури щодо тлумачення понять, які вивчаються; виокремлено спільні та відмінні риси; обгрунтовано власне бачення досліджуваних явищ.

Ключові слова: самостійна робота, індивідуальна робота, позааудиторна робота, самоосвіта, самостійність. 